\title{
Fibrin Deposition in Tissues from Endotoxin-treated Mice Correlates with Decreases in the Expression of Urokinase-Type but Not Tissue-Type Plasminogen Activator
}

\author{
Koji Yamamoto and David J. Loskutoff \\ Department of Vascular Biology, The Scripps Research Institute, La Jolla, California 92037
}

\begin{abstract}
The primary hypothesis of this report is that the formation and subsequent removal of fibrin in specific tissues during pathologic processes reflects temporal changes in the local expression of key procoagulant and fibrinolytic genes. To begin to test this hypothesis, we have used quantitative PCR assays and in situ hybridization analysis to examine the effects of endotoxin on the expression of specific genes in murine tissues, and to relate these changes to fibrin deposition/ dissolution using immunohistochemical approaches. Endotoxin caused large increases in plasminogen activator inhibitor-1 mRNA and modest increases in tissue factor mRNA in most tissues examined. However, fibrin was only detected in the kidneys and adrenals of endotoxin-treated mice, and it was transient. Unexpectedly, changes in urokinase-type plasminogen activator mRNA but not tissue-type plasminogen activator mRNA correlated with fibrin deposition/dissolution in these tissues. Pretreatment of mice with the fibrinolytic inhibitor epsilon-aminocaproic acid before endotoxin increased both the number of fibrin-positive tissues and the duration of fibrin deposition in the kidneys and adrenals. These results suggest that the absence of fibrin in some tissues reflects ongoing local fibrinolysis, and that increases in plasminogen activator inhibitor-1 and tissue factor gene expression and decreases in urokinase-type plasminogen activator expression are necessary for tissue-specific fibrin deposition. Changes in tissue-type plasminogen activator gene expression do not appear to be essential for fibrin deposition/dissolution in this murine model of sepsis. $(J$. Clin. Invest. 1996. 97:2440-2451.) Key words: plasminogen activator inhibitor-1 - tissue factor $\bullet$ thrombosis $~$ gene expression • endotoxemia
\end{abstract}

\section{Introduction}

Sepsis caused by gram-negative bacteria is frequently associated with thrombotic complications manifested as dissemi-

This work was presented in part at the 5th International Workshop on Molecular and Cellular Biology of Plasminogen Activation, 1-6 August 1995, in Hameenlinna, Finland.

Address correspondence to Dr. D.J. Loskutoff, Department of Vascular Biology, VB-3, The Scripps Research Institute, 10666 North Torrey Pines Rd., La Jolla, CA 92037. Phone: 619-784-7125; FAX: 619-784-7353.

Received for publication 12 December 1995 and accepted in revised form 6 March 1996.

J. Clin. Invest.

(C) The American Society for Clinical Investigation, Inc.

0021-9738/96/06/2440/12 \$2.00

Volume 97, Number 11, June 1996, 2440-2451 nated intravascular coagulation $(\mathrm{DIC})^{1}(1,2)$. Septic shock with multiple organ failure is characterized histologically by cell damage, tissue necrosis, and vascular disruption because of microvascular and extravascular fibrin deposition in many organs (3). Endotoxin (lipopolysaccharide, LPS), one of the toxic principles of gram-negative bacteria, activates inflammatory cells, causing them to synthesize and release several endogenous mediators that contribute to the pathophysiologic process of septic shock (4). Studies in animals and in cultured cells have shown that a procoagulant state develops after exposure to LPS, and that this condition is largely due to the conversion of the endothelium from a thromboresistant to a thrombogenic surface (5). However, the molecular link between sepsis and intravascular or extravascular thrombosis remains to be elucidated.

Tissue factor (TF) is the primary cellular initiator of the coagulation protease cascade (6) and serves as a cell-surface receptor and specific cofactor for plasma Factors VII/VIIa (7). Activation of this cascade results in the generation of thrombin and the conversion of fibrinogen into fibrin. Exposure of endothelial cells and monocytes to LPS in vitro induces the expression of $\mathrm{TF}(8,9)$. Aberrant expression of TF may be responsible for thrombotic episodes in patients with a variety of clinical disorders, including gram-negative sepsis (10). In addition, there is in vivo evidence indicating that TF plays a significant role in the coagulation response during endotoxemia in rabbits and baboons $(11,12)$, and that TF mRNA is upregulated in kidneys and lungs of LPS-injected mice (13).

Plasminogen activators (PAs) are serine proteases that convert the zymogen plasminogen into the active serine protease plasmin (14), the primary enzyme responsible for the removal of fibrin deposits. There are two types of PAs, tissuetype (t-PA) and urokinase-type (u-PA), and these are the products of separate genes (15). t-PA is synthesized by endothelial cells in normal blood vessels (16) and displays relatively high affinity for fibrin (17), suggesting that it functions predominantly in physiological thrombolysis in vivo (18). In contrast, u-PA is produced and secreted by a variety of migrating cell types $(15,19)$ and binds to and functions on a cell surface receptor (20). It is considered to be involved primarily in extracellular proteolysis accompanying tissue remodeling and cell invasion $(15,21)$. Plasminogen activator inhibitor-1 (PAI-1) is a rapid and specific inhibitor of both t-PA and u-PA and may be the primary regulator of plasminogen activation in vivo (22). Elevations in PAI-1 activity also have been demonstrated in a number of clinical conditions associated with a predisposition to thrombosis $(23,24)$, including sepsis. In this re-

1. Abbreviations used in this paper: DIC, disseminated intravascular coagulation; EACA, epsilon-aminocaproic acid; PAs, plasminogen activators; PAI-1, plasminogen activator inhibitor-1; RT, reverse transcription; TF, tissue factor; t-PA, tissue-type plasminogen activator; u-PA, urokinase-type plasminogen activator. 
gard, PAI-1 mRNA is induced by LPS in rat (25) and murine tissues (26) and this increase is detected primarily in vascular endothelial cells (27). PAI-1 mRNA is also positively regulated by tumor necrosis factor- $\alpha$ and transforming growth factor- $\beta$ (TGF- $\beta$ ) (26).

In spite of the increasing number of reports about the effects of LPS on the synthesis of t-PA, u-PA, PAI-1, and TF in vivo, information about how these changes in gene expression contribute to fibrin deposition in tissues is lacking. In this report, we used PCR-based assays to investigate the effects of LPS on t-PA, u-PA, PAI-1, and TF gene expression in various murine tissues and immunohistochemical staining to relate these changes to fibrin deposition/dissolution. Fibrin deposition was detected only in kidneys and adrenals of LPS-treated mice, and this pathological condition correlated with significant increases in PAI-1 and TF gene expression and dramatic decreases in u-PA. Fibrin was not detected in other tissues with less remarkable decreases in u-PA mRNA, and changes in t-PA expression did not appear to correlate with fibrin deposition or dissolution in this model. These observations suggest that fibrin deposition/dissolution in tissues is regulated by temporal changes in the local expression of TF and PAI-1, and that alterations in u-PA gene expression play a critical role in these processes.

\section{Methods}

\section{Experimental protocols}

2-mo-old adult male CB6 mice $(\mathrm{BALB} / \mathrm{c} / \mathrm{ByJ} \times \mathrm{C} 57 \mathrm{~B} 16 / \mathrm{J}$; Scripps Clinic Rodent Breeding Colony, La Jolla, CA), weighing 25-30 grams, were used for all experiments. Mice were injected intraperitoneally either with $50 \mu \mathrm{g}$ LPS $(2.0 \mathrm{mg} / \mathrm{kg}$ ) (Escherichia coli serotype O111:B4; Sigma Chemical Co., St. Louis, MO) in $200 \mu$ l of saline (Baxter Healthcare Corp., Deerfield, IL), or with saline vehicle alone. At the indicated times, the mice were killed by overdose inhalation anesthesia with methoxyflurane (Pitman-Moore, Mundelein,
IL), and immediately perfused for 15 min through the left ventricle into the opened vena cava at an approximate rate of $600 \mu \mathrm{l} / \mathrm{min}$ of cold PBS using a peristaltic pump. Large perfusion volumes were used to remove contaminating fibrinogen from the blood vessels, and immunohistochemical staining using the antifibrinogen/fibrin antibody demonstrated the success of this approach (see below). The tissues were perfused further with chilled $4 \%$ paraformaldehyde for 15 min, and then removed surgically, fixed overnight in fresh $4 \%$ paraformaldehyde, and embedded in paraffin. In some experiments, mice were preinjected intraperitoneally with $200 \mu \mathrm{l}$ of saline containing 20 $\mathrm{mg}$ epsilon-aminocaproic acid (EACA) to reach a final concentration of $50 \mathrm{mM}$ in plasma (28) $1 \mathrm{~h}$ before LPS injection. The tissues were then perfused, removed, and fixed as above. Total RNA was prepared from unfixed tissues by the acid guanidium thiocyanate-phenol-chloroform method as previously described (29) and then quantitated by measuring absorption at $260 \mathrm{~nm}$. The integrity of the $18 \mathrm{~S}$ and $28 \mathrm{~S}$ ribosomal RNA was monitored by electrophoresing $10 \mu \mathrm{g}$ of total RNA through a $1.2 \%$ agarose/formaldehyde gel.

\section{Quantitative PCR}

The following reagents and approaches were used.

Oligonucleotide primers for PCR amplification. The sequences of oligonucleotide primers used both for the construction of the control plasmid and for PCR amplification are shown in Table I. The expected size of the predicted PCR products resulting from endogenous mRNA or from the cRNA standard is also shown. We designed and synthesized primers for a number of potential target murine genes, including t-PA (30), u-PA (31), PAI-1 (32), TF (33), TGF- $\beta$ (34), vitronectin (35), von Willebrand factor (36), and $\beta$-actin (37), using a DNA synthesizer (Applied Biosystems, Inc., Foster City, CA). In addition, complementary linkers that span adjacent primers (38) for target genes were also synthesized.

Construction of PCR template. A synthetic DNA template composed of oligomers specific for a variety of fibrinolytic and coagulation genes (Table I) was constructed by cloning fragments containing either $5^{\prime}$ or $3^{\prime}$ primers into pBluescript II KS+ (Stratagene, La Jolla, CA). Briefly, individually phosphorylated $5^{\prime}$ and $3^{\prime}$ primers, together with their complementary linkers as described above, were mixed together, heated at $95^{\circ} \mathrm{C}$ for $10 \mathrm{~min}$, and annealed by slowly cooling to

Table I. Sequences of Oligonucleotides Used as 5' and 3' Primers for Eight Target Genes

\begin{tabular}{|c|c|c|c|c|}
\hline \multirow[b]{2}{*}{ Gene } & \multirow[b]{2}{*}{ Primer sequences } & \multirow[b]{2}{*}{ Position } & \multicolumn{2}{|c|}{ Size of PCR product (bp) } \\
\hline & & & mRNA & cRNA standard \\
\hline & & $n t$ & & \\
\hline \multirow[t]{2}{*}{ PAI-1 } & 5' - TCAGAGCAACAAGTTCAACTACACTGAG & $809-836$ & 540 & 438 \\
\hline & 3' - CCCACTGTCAAGGCTCCATCACTTGCCCCA & $1318-1348$ & & \\
\hline \multirow[t]{2}{*}{$\mathrm{t}-\mathrm{PA}$} & 5' - CTGAGGTCACAGTCCAAGCAATGT & $1321-1344$ & 564 & 144 \\
\hline & 3' - GCTCACGAAGATGATGGTGTAAAGA & $860-1884$ & & \\
\hline \multirow[t]{2}{*}{$\mathrm{u}-\mathrm{PA}$} & 5' - GCTCCTATAATCCTGGAGAGATGAA & $841-865$ & 672 & 172 \\
\hline & 3'-ACCTGTCTTTTCAGCTTCTTCCCTCC & $1487-1512$ & & \\
\hline \multirow[t]{2}{*}{$\mathrm{TF}$} & 5' - CGGGTGCAGGCATTCCAGAG & $185-204$ & 242 & 212 \\
\hline & 3' - CTCCGTGGGACAGAGAGGAC & $407-426$ & & \\
\hline \multirow[t]{2}{*}{$\beta$-Actin } & 5' - TGGAATCCTGTGGCATCCATGAAAC & $886-910$ & 349 & 293 \\
\hline & $3^{\prime}-$ TAAAACGCAGCTCAGTAACAGTCCG & $1210-1234$ & & \\
\hline \multirow[t]{2}{*}{ vWf } & 5' - ATGATGGAGAGGTTACACATC & $4015-4035$ & 1130 & 172 \\
\hline & 3'- GGCAGTTGCAGACCCTCCTTG & $5124-5144$ & & \\
\hline \multirow[t]{2}{*}{$\mathrm{VN}$} & 5' - CATCACGTTCAATCTCGTTCTCTTT & $1184-1208$ & 304 & 193 \\
\hline & $3^{\prime}-$ TTGGGCTGGGAGAAAGAGATGAGG & $1464-1487$ & & \\
\hline \multirow[t]{2}{*}{ TGF- $\beta$} & 5' - CTCCCACTCCCGTGGCTTCTAG & $389-410$ & 472 & 380 \\
\hline & 3'- GTTCCACATGTTGCTCCACACTTG & $837-860$ & & \\
\hline
\end{tabular}

$V N$, vitronectin. 
$15^{\circ} \mathrm{C}$. The mixture of oligonucleotides was ligated together using $6 \mathrm{U}$ of T4 ligase (Boehringer Mannheim Corp., Indianapolis, IN) at $15^{\circ} \mathrm{C}$ for $15 \mathrm{~h}$. The resulting fragment was filled in using $2.5 \mathrm{U}$ of Taq polymerase (Gibco Laboratories, Grand Island, NY), amplified by PCR for 30 cycles using the outermost primers, and cloned into the multicloning site (XbaI/KpnI) of pBluescript II KS+. The sequence of the final fragment was confirmed by DNA sequence analysis.

Synthesis of the cRNA standard. The above plasmid was linearized by digestion with KpnI, and a cRNA standard was prepared from it by in vitro transcription from the $\mathrm{T} 7$ promoter using the Riboprobe Gemini II in vitro transcription system according to the manufacturer's instructions (Promega Corp., Madison, WI). The cRNA was subsequently treated with RNase-free RQ1 DNase (Promega) to remove the template DNA, extracted twice with phenol/chloroform, ethanol precipitated, and quantified by absorbance at $260 \mathrm{~nm}$. Finally, the purified cRNA standard (523 nucleotides) was adjusted to a concentration of $10^{12}$ molecules $/ \mu 1$.

Quantitative determination of $m R N A$ for target genes by competitive RT-PCR. The cRNA standard described above was used to determine the concentration of each target mRNA in murine tissues according to the procedure described by Wang et al. (39). To estimate the amount of cRNA standard required to achieve approximately equal band intensity after PCR (30 cycles) for both the target and the standard products, $1 \mu \mathrm{g}$ of total tissue RNA from control mice was reverse transcribed in the presence of 10 -fold serial dilutions of cRNA standard. The reverse transcription (RT) and PCR were carried out using a Gene Amp RNA PCR kit (Perkin-Elmer/Cetus Corp., Norwalk, CT), as previously described (40). Thereafter, $1 \mu \mathrm{g}$ of total tissue RNA and a fixed amount of cRNA standard as determined above were combined and reverse transcribed. To ensure the linearity of the amplification reaction, serial twofold dilutions of the RT mixture were amplified through 30 cycles. The PCR amplification solution contained $50 \mathrm{mM} \mathrm{KCl}, 10 \mathrm{mM}$ Tris- $\mathrm{HCl}(\mathrm{pH} 8.3), 2 \mathrm{mM}$ $\mathrm{MgCl}_{2}, 0.15 \mu \mathrm{M}$ of $5^{\prime}$ primer including $5 \times 10^{5} \mathrm{cpm}$ of ${ }^{32} \mathrm{P}$-end-labeled oligonucleotide, $0.15 \mu \mathrm{M}$ of $3^{\prime}$ primer, and $1 \mathrm{U}$ of Taq polymerase. To quantitate the results, $20 \mu \mathrm{l}$ of each PCR reaction mixture was electrophoresed on a 2 or $2.5 \%$ agarose gel, and the gels were stained using ethidium bromide. The respective bands were excised from the gel using a razor blade, and the incorporated radioactivity was determined using unquenched scintillation counting. Radioactivity in the PCR product was plotted against the template concentration, using a double-logarithmic scale, and the number of molecules of target mRNA was determined as described (39) by extrapolation using the cRNA standard curve. The estimation of the concentration of each endogenous target mRNA was calculated as follows:

\section{$\frac{\text { pg target mRNA }}{\mu \mathrm{g} \text { of total tissue RNA }}=$$$
\underline{\text { No. of molecules of target mRNA }} \times
$$$$
\mu \mathrm{g} \text { of total tissue RNA }
$$ \\ $\underline{\text { [No. of nucleotides of full-length mRNA for target gene] } \times 321 \times 10^{12}}$

$$
6.023 \times 10^{23}
$$

where No. of nucleotides of full-length mRNA is 3,200 for PAI-1; 1,800 for TF; 2,800 for t-PA; 2,300 for $\mathrm{u}-\mathrm{PA}$; where 321 is the average molecular weight of one base; and where $6.023 \times 10^{23}$ is Avogadro's number.

\section{Riboprobe preparation}

The EcoRI/SphI fragment containing nucleotides 1-1085 of the mouse PAI-1 cDNA (32) and the 821-bp mouse TF cDNA fragment containing nucleotides 229-1049 (13) were cloned into the vector pGEM-3Z (Promega), respectively. Both the 2519-bp EcoRI fragment of the mouse t-PA cDNA (30), subcloned into the vector pBluescript II KS+, and the 1983-bp XbaI/SmaI fragment of the mouse u-PA cDNA (31), subcloned into the vector pSP64 (Promega), were provided by Dr. S. Strickland (State University of New York).
The 1076-bp XbaI/HindIII fragment of the mouse u-PA cDNA was then cloned into the vector pGEM-3Z. These vectors were linearized and used as templates for in vitro transcription of radiolabeled antisense or sense riboprobes using SP6, T3, or T7 RNA polymerase (Promega), respectively, in the presence of $\left[{ }^{35} \mathrm{~S}\right] \mathrm{UTP}(>1,200 \mathrm{Ci} /$ mmol; Amersham Corp., Arlington Heights, IL).

\section{In situ hybridization}

In situ hybridizations were performed as described previously (41). After hybridization, the slides were dehydrated by immersion in a graded alcohol series containing $0.3 \mathrm{M} \mathrm{NH}_{4} \mathrm{Ac}$, dried, and either placed directly on XAR-5 film (Eastman Kodak, Rochester, NY), for regional autoradiography, or coated with emulsion for high resolution autoradiography. For regional autoradiography, the films were developed and photographed after incubation in the dark at room temperature for $2 \mathrm{wk}$. For high resolution autoradiography, the slides were coated with NTB2 emulsion (Kodak; 1:2 in water), and exposed in the dark at $4^{\circ} \mathrm{C}$ for 3-8 wk. Slides were developed for $2 \mathrm{~min}$ in D19 developer (Kodak), fixed, washed in water $(3 \times 5 \mathrm{~min})$, and counterstained with hematoxylin and eosin. In all cases, parallel sections were analyzed using a sense probe as the control for nonspecific hybridization. No specific hybridization signal could be detected in these control hybridizations.

\section{Immunohistochemistry}

Immunohistochemical staining was performed using the HISTOSTAIN-SP kit (Zymed Laboratories, South San Francisco, CA), as described previously (41) with minor modifications. Briefly, the tissue sections were deparaffinized, treated with $2 \%$ hydrogen peroxide, and incubated with $10 \%$ normal goat serum for $30 \mathrm{~min}$. The slides were then incubated with $10 \mu \mathrm{g} / \mathrm{ml}$ of rabbit anti-mouse fibrinogen/ fibrin antibody (a kind gift of Dr. E. Plow, Cleveland Clinic) containing $0.1 \%$ goat serum at $4^{\circ} \mathrm{C}$ overnight, followed by incubation for $1 \mathrm{~h}$ at $25^{\circ} \mathrm{C}$. In control experiments, tissues were incubated with preimmune (normal) rabbit IgG instead of the primary antibody. The slides were then washed and treated sequentially with biotinylated goat anti-rabbit IgG (Zymed Laboratories), streptavidin-peroxidase conjugate (Zymed Laboratories), and aminoethylcarbazole chromogen containing $0.03 \%$ hydrogen peroxide (Zymed Laboratories). After rinsing in distilled water, the slides were counterstained with Gill's modified hematoxylin, rinsed well with tap water, and mounted in GVA-mount (Zymed Laboratories). Although the antiserum used for these experiments detects both fibrinogen and fibrin, contaminating fibrinogen did not appear to be a problem. The specificity of the antibody for fibrin in the extensively perfused tissues was indicated by the absence of staining in all tissues from control mice and most tissues from LPS-treated mice (see for example Figs. 5-7).

\section{Results}

Distribution of $t-P A, u-P A, P A I-1$, and TF mRNAs in normal murine tissues. To examine the expression of the t-PA, u-PA, PAI-1, and TF genes in vivo, total RNA was extracted from tissues of adult male CB6 mice and the concentration of each mRNA was determined by PCR-based assays as described in Methods. In the initial experiments, the level of each target mRNA was examined semiquantitatively by RT-PCR using 1 $\mu \mathrm{g}$ total tissue RNA in the presence of $10^{5}$ molecules of cRNA standard (Fig. $1 A$ ). The relative expression level of the target mRNA in the tissues was approximated by comparing the ratio between the intensities of the target and standard band for each gene. The concentration of each mRNA was then determined in separate experiments (Fig. $1 B$ ) using quantitative PCR as described in Methods. In brief, t-PA mRNA was detected in all tissues examined, although the concentrations var- 

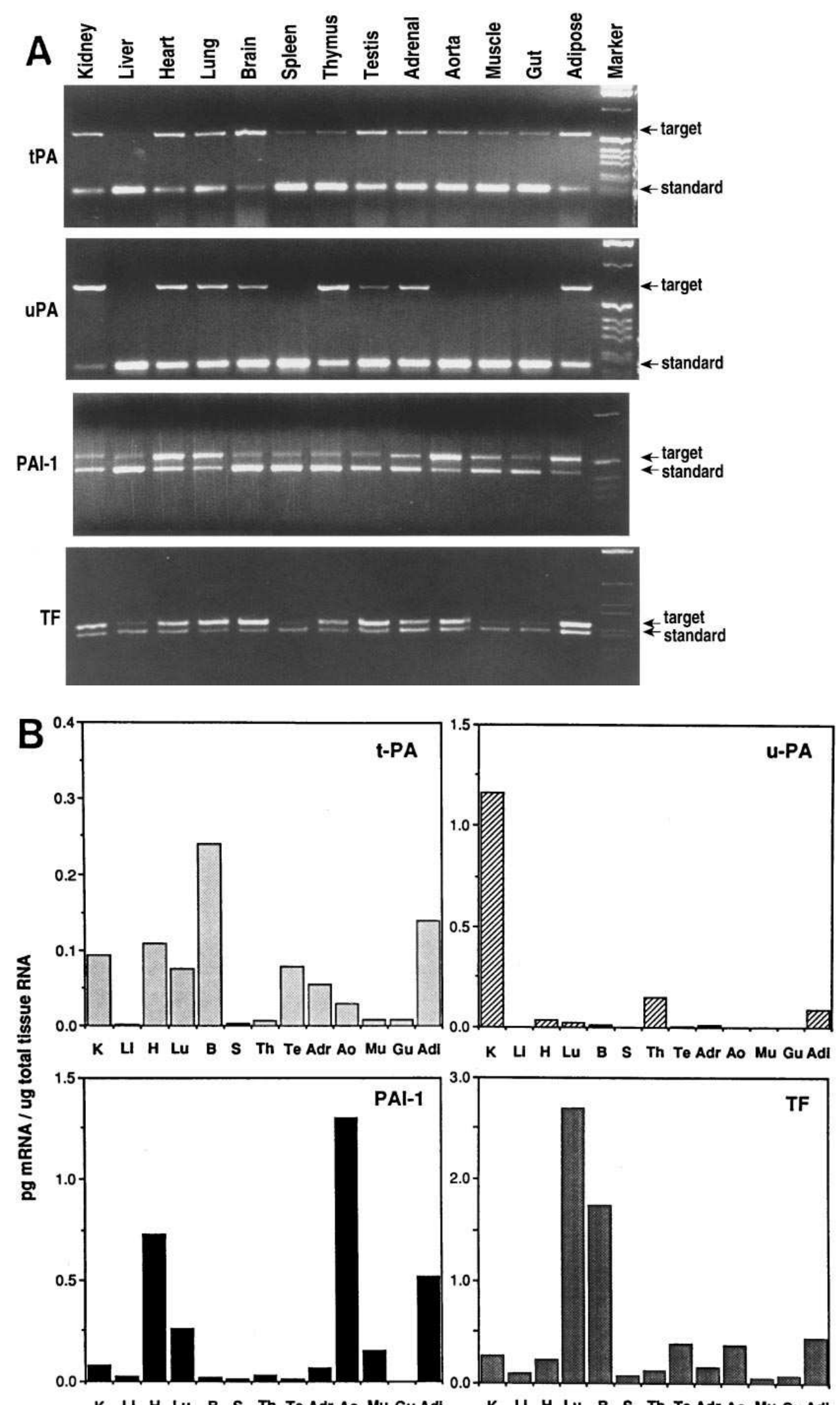

K LI H Lu B S Th Te Adr Ao Mu GuAdI

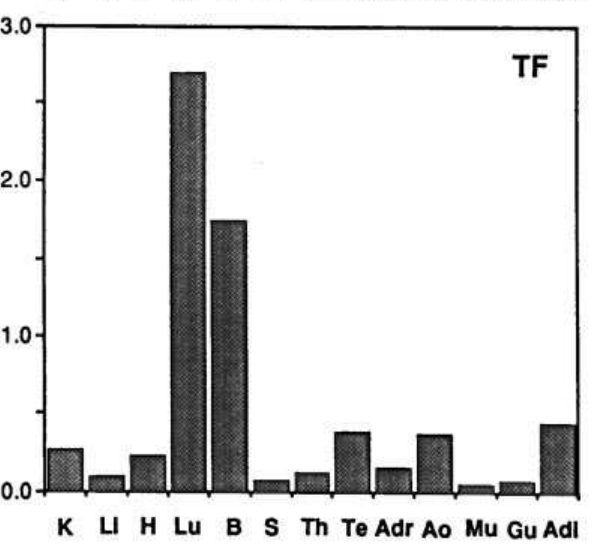

Figure 1. Tissue distribution of t-PA, u-PA, PAI-1, and TF mRNAs. (A) Competitive PCR was performed after co-RT using $1 \mu \mathrm{g}$ total tissue RNA and $1 \times 10^{5}$ molecules of cRNA standard. The PCR products were fractionated by $2 \%$ agarose gel electrophoresis and stained with ethidium bromide. In each case, the top band is the PCR product derived from the endogenous (target) mRNA and the bottom band is the PCR product from the cRNA standard. The size of each PCR product is shown in Table I. The relative concentration of each mRNA in the tissues can be approximated by comparing the intensity of bands between the target and the standard. (B) The results shown in $A$ were used to optimize the relative concentration of cRNA standard to be used in the more quantitative assay using ${ }^{32} \mathrm{P}$-labeled primers as described in Methods. The concentration of each mRNA in the tissues is expressed as picograms of specific mRNA per microgram of total tissue RNA. Each value is the mean for three independent experiments from three adult CB6 mice. $K$, kidney; $L i$, liver; $H$, heart; $L u$, lung; $B$, brain; $S$, spleen; $T h$, thymus; $T e$, testis; $A d r$, adrenal; $A o$, aorta; $M u$, muscle; $G u$, gut; $A d i$, adipose. ied over a wide range. The highest concentration was in the brain, followed by the adipose tissue, heart, kidney, testis, and lung. The distribution of u-PA mRNA was more restricted than that of t-PA since it could only be detected in 8 of the 13 tissues examined. The kidney contained by far the highest concentration, followed by the thymus and adipose tissue. Relatively low concentrations of u-PA mRNA were present in the heart, lung, adrenal, brain, and testis, and none was detected in 
the liver, spleen, gut, aorta, and skeletal muscle, even after 35 cycles of PCR amplification in the absence of cRNA standard (data not shown). PAI-1 mRNA was also detected in all tissues examined, with the aorta containing the highest concentration, followed by the heart, adipose tissue, and lung. Surprisingly, TF mRNA was also detected in all tissues examined, with the highest concentration in the lung and brain. Intermediate levels of TF mRNA were present in the adipose tissue, testis, aorta, kidney, and heart.

Effects of LPS on the levels of t-PA, u-PA, PAI-1, and TF $m R N A s$ in various tissues. LPS has been reported to alter the expression of many hemostatic genes in vivo $(42,43)$. Fig. 2 shows the time courses for LPS-induced changes in the levels of t-PA, u-PA, PAI-1, and TF mRNAs in several tissues. Maximal induction of PAI-1 mRNA (Fig. 2, closed circles) was observed at $3 \mathrm{~h}$ in the kidney (56-fold), lung (28-fold), adrenal (25-fold), and heart (7-fold). Although not shown, the greatest induction of PAI-1 mRNA occurred in the liver where it was increased 110 -fold at $3 \mathrm{~h}$ and 200 -fold at $8 \mathrm{~h}$ after LPS-administration. Endotoxin injection also caused a slight increase in t-PA mRNA (Fig. 2, open squares) in all tissues examined. In contrast to these results, u-PA mRNA (Fig. 2, open circles) was markedly decreased in the kidney (85\% reduction), adrenal (79\%), and heart (76\%) within $8 \mathrm{~h}$ after LPS. LPS did not alter the level of u-PA mRNA in the lung. u-PA and t-PA mRNAs in the liver were too low to be quantitated either before or after LPS (not shown). Finally, expression of TF (Fig. 2, closed squares) was elevated in the kidney (three- to sixfold), lung (two- to threefold), and adrenal (two- to threefold), while it was decreased in the heart (70-80\% reduction) and liver (50$80 \%$ decrease; not shown) at 3 and $8 \mathrm{~h}$ after LPS treatment. We observed no significant changes in the concentration of the four mRNAs in the brain after LPS (data not shown). $\beta$-Actin mRNA levels remained unchanged after LPS injection in all tissues examined (data not shown).

Localization of $t-P A, u-P A, P A I-1$, and TF mRNAs in the kidney. The distribution and effects of LPS on the expression of t-PA, u-PA, PAI-1, and TF mRNAs in the kidney were determined at the regional level by hybridizing kidney sections to ${ }^{35}$ S-labeled cRNA probes and analyzing the results by autoradiography (Fig. 3). PAI-1 mRNA was not visible in control kidney but dramatically increased throughout the kidney at 3 and $8 \mathrm{~h}$ after LPS injection, declining to basal levels by $24 \mathrm{~h}$ (Fig. 3, $A-D)$. In contrast, u-PA mRNA was most prominent in the medulla of control kidney (Fig. $3 E$ ) and specifically decreased in this region at 3 and $8 \mathrm{~h}$ after LPS injection (Fig. 3, $F$ and $G$ ). The concentration of u-PA mRNA returned to control levels by $24 \mathrm{~h}$ (Fig. $3 H$ ). t-PA mRNA was mainly detected in the renal cortex and the papilla and appeared to increase slightly at 3 and $8 \mathrm{~h}$ after LPS (Fig. 3, $I-L$ ). Although TF mRNA was not detected in control kidney, it was induced by LPS in the renal cortex, with the maximal increase at $8 \mathrm{~h}$ (Fig. 3, $M-P$ ). In general, these observations agree with the data obtained by quantitative PCR (Fig. 2).

High resolution microscopic analysis of the in situ hybridization slides (Fig. 4) not only confirmed the results shown in Fig. 3, but also extended them by providing insights into the identity of the positive cells. For example, although no PAI-1 mRNA was detected in the control kidney (Fig. $4 A$ ), a strong hybridization signal was apparent in the glomeruli and in the peritubular regions of kidneys from LPS-treated mice (Fig. 4 $B)$. The positive cells in these regions were previously identified as glomerular and peritubular endothelial cells (41). The strong signal for u-PA in control kidney (Fig. $3 E$ ) was also lo-

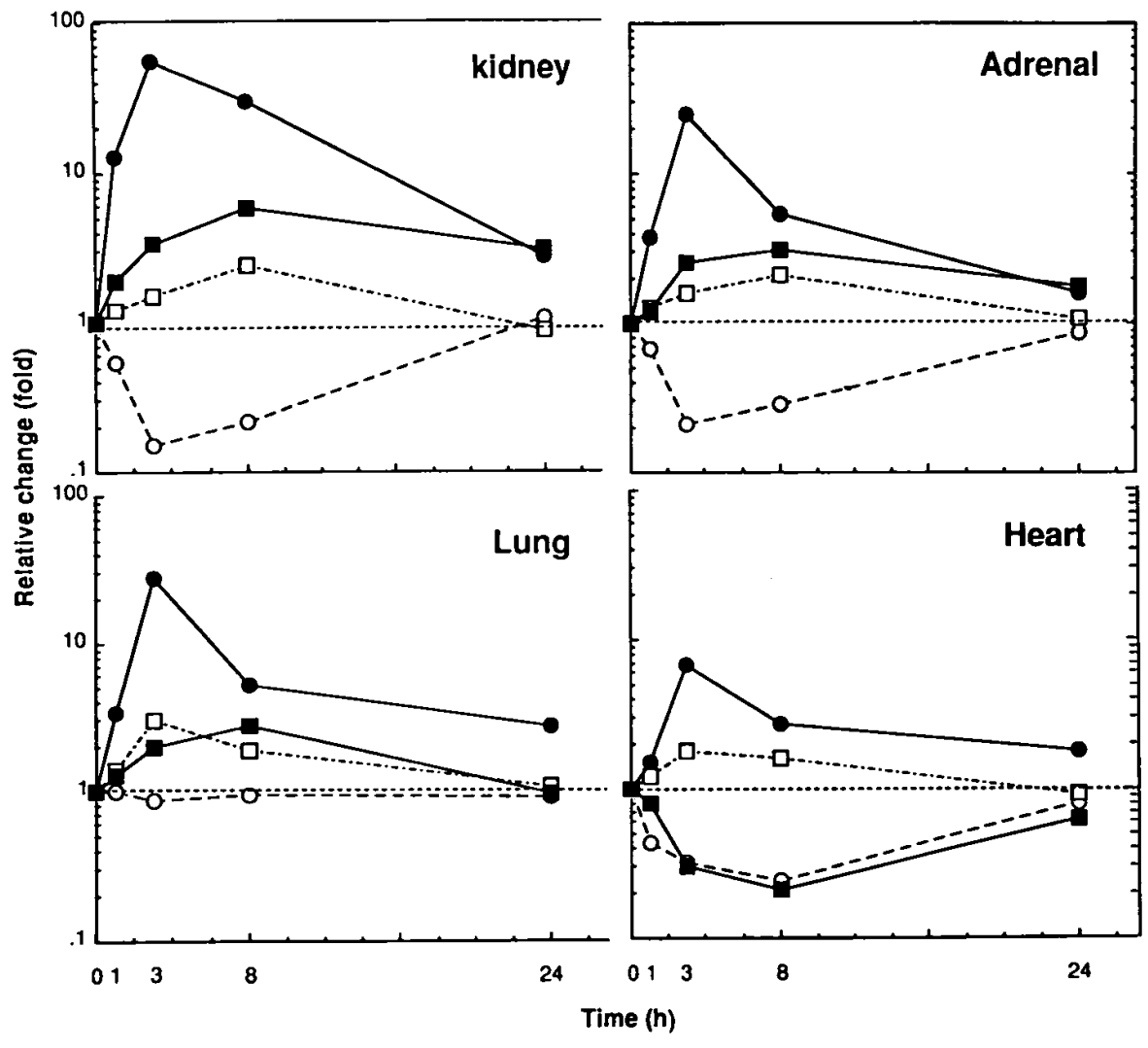

Figure 2. Kinetics of LPS-induced changes in t-PA, u-PA, PAI-1, and TF mRNA levels in murine tissues. Mice were injected intraperitoneally with either $50 \mu \mathrm{g}$ LPS or with saline alone (control) and selected tissues (kidney, adrenal, lung, and heart) were removed at the indicated times $(1,3,8$, and $24 \mathrm{~h})$. Total RNA was prepared and analyzed for t-PA (open boxes), u-PA (open circles), PAI-1 (filled circles), and TF (filled boxes) mRNA by quantitative PCR as described in Methods. The data points represent the average of three sets of independent experiments. The data are plotted as the relative change (fold) in mRNA levels for each tissue, determined as the ratio of the level in the tissues after LPS treatment divided by the level in the untreated control tissue (0 time point). 


\section{Control}

A

\section{PAl-1}

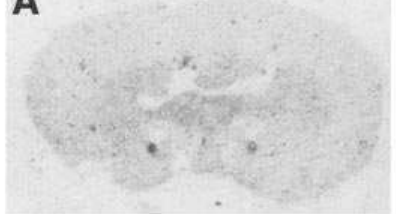

u-PA

E
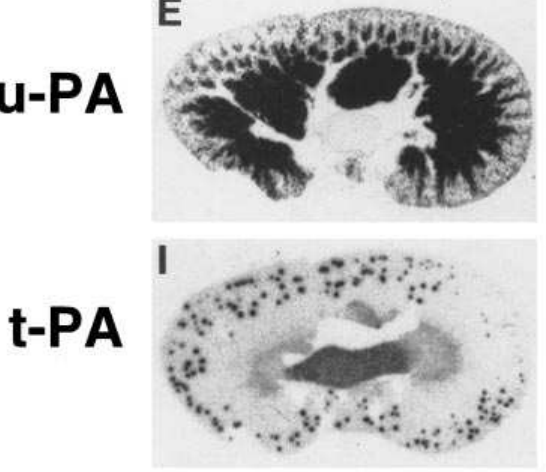

TF
LPS 3h

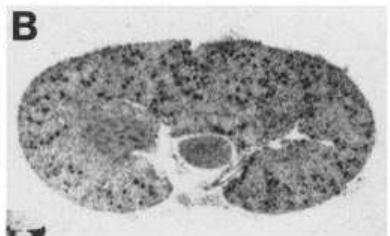

$F$
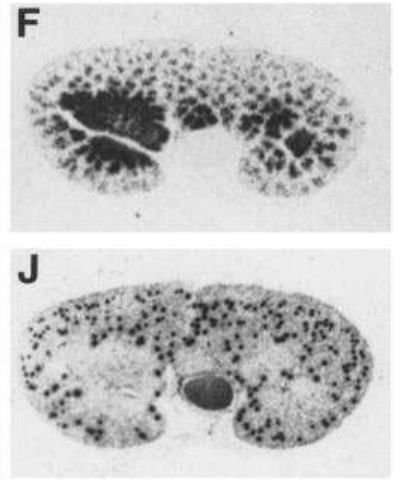

N

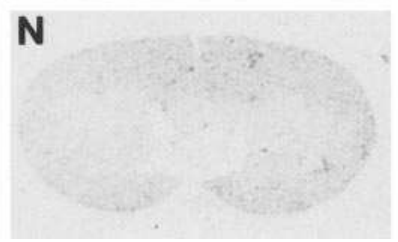

LPS $8 \mathrm{~h}$

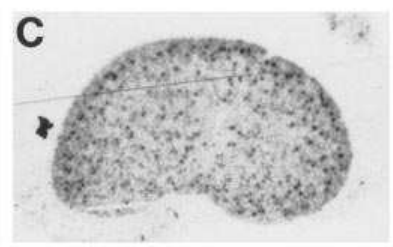

G
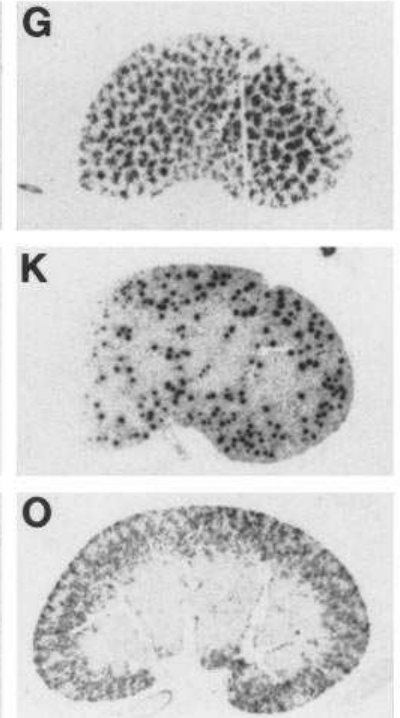

LPS 24h
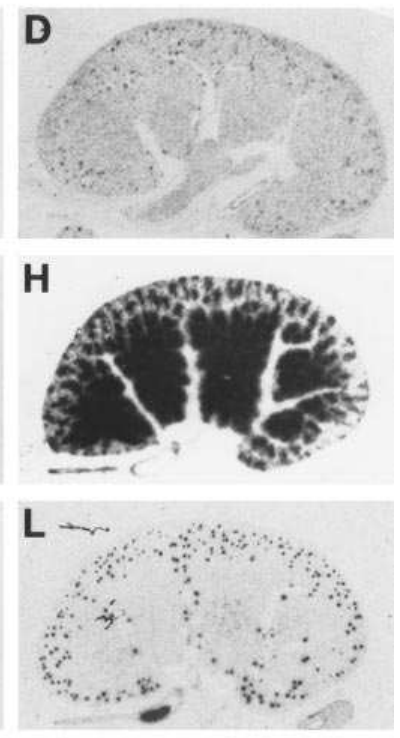

P

Figure 3. Distribution and effects of LPS on the expression of t-PA, u-PA, PAI-1, and TF mRNAs in the kidney. Kidney sections from untreated control mice and mice treated with LPS were analyzed by in situ hybridization using ${ }^{35}$-labeled cRNA probes. The sections were incubated on $\mathrm{x}$-ray film and photographed after 2 wk of exposure at room temperature. $(A-D)$ Hybridization signals (black grains) for PAI-1 mRNA in kidneys from control mice $(A)$ and mice treated with LPS for $3(B), 8(C)$, and $24 \mathrm{~h}(D) ;(E-H)$ u-PA mRNA in kidneys from control mice $(E)$ and mice treated with LPS for $3(F), 8(G)$, and $24 \mathrm{~h}(H) ;(I-L)$ t-PA mRNA in kidneys from control mice $(I)$ and mice treated with LPS for $3(J), 8$ $(K)$, and $24 \mathrm{~h}(L) ;(M-P)$ TF mRNA in kidneys from control mice $(M)$ and from mice treated with LPS for $3(N)$, $8(O)$, and $24 \mathrm{~h}(P)$. No specific hybridization signal could be detected in parallel sections using ${ }^{35} \mathrm{~S}$-labeled sense probes for nonspecific hybridization.

calized to tubular epithelial cells (Fig. $4 C$ ) and it was reduced significantly by LPS (Fig. $4 \mathrm{D}$ ). The t-PA signal in control kidney (Fig. $3 I$ ) was localized to unidentified cells within the glomeruli (Fig. $4 E$ ) and it appeared to be increased in kidneys from LPS-treated mice (Fig. $4 F$ ). Finally, no TF mRNA was detected in control kidneys (Fig. $4 G$ ) but a strong signal was apparent in tubular epithelial cells (Fig. $4 H$ ) of kidneys from LPS-treated mice.

Fibrin deposition in the tissues of LPS-treated mice. Experiments were performed to determine whether these local changes in the expression of procoagulant and fibrinolytic genes (Figs. 2-4) correlated with fibrin deposition/dissolution in these tissues. In these experiments, the presence of fibrin was evaluated using immunohistochemical staining as described in Methods. Fibrin was not detected in control kidneys using this approach (Fig. $5 \mathrm{~A}$ ), but it was readily demonstrated in glomerular and peritubular capillaries in the kidney at $3 \mathrm{~h}$ after LPS injection (Fig. $5 \mathrm{~B}$ ). However, the presence of fibrin was transient, decreasing at $8 \mathrm{~h}$ and disappearing by $24 \mathrm{~h}$ (Fig. 5, $C$ and $D$ ). A similar pattern of transient fibrin deposition in microvessels was also observed in adrenals from LPS-treated animals (Fig. 5, $E-H$ ). In contrast to these results, fibrin was not detected at any time in other tissues examined, including the lung, heart, liver, and brain (Fig. 6, $A-D$ ).

Effect of EACA on fibrin deposition in tissues from LPStreated mice. One possibility to account for the absence of fi- brin in many tissues from LPS-treated mice (e.g., lung, heart, liver, and brain) is that fibrin is formed in these tissues but rapidly lysed because of ongoing endogenous fibrinolysis. One way to test this hypothesis is to eliminate the influence of the fibrinolytic system in LPS-treated mice. Thus, mice were pretreated with EACA to inhibit plasminogen activation, and then treated with LPS. Under these conditions, we observed microvascular fibrin deposition in the lung, heart, and liver at 3 and $8 \mathrm{~h}$ after LPS injection (e.g., in microvessels in the myocardium, in pulmonary capillaries surrounding alveoli, and in sinusoids in the liver; Fig. $6, E-G)$. We attempted to quantitate these results by counting the number of fibrin-positive fields per 30 microscopic fields in various tissue sections. As Fig. 7 demonstrates, fibrin was not detected in any tissues from mice treated with EACA alone ( 0 time points), while fibrin in the lung, heart, and liver was dramatically increased after treatment with both EACA and LPS. Moreover, the presence of fibrin in kidneys and adrenals from EACA-pretreated mice was apparent for longer periods of time than in mice treated with LPS alone. Although no fibrin was detected in the brain at $3 \mathrm{~h}$ after treatment with EACA and LPS (Fig. $6 H$ ), very low levels were detected at $8 \mathrm{~h}$ after treatment with both agents (Fig. 7). In general, fibrin deposition was still transient, even in the presence of EACA. The transient nature of the fibrin in the presence of EACA probably reflects the fact that the half-life of EACA is relatively short (44). In any case, these results 


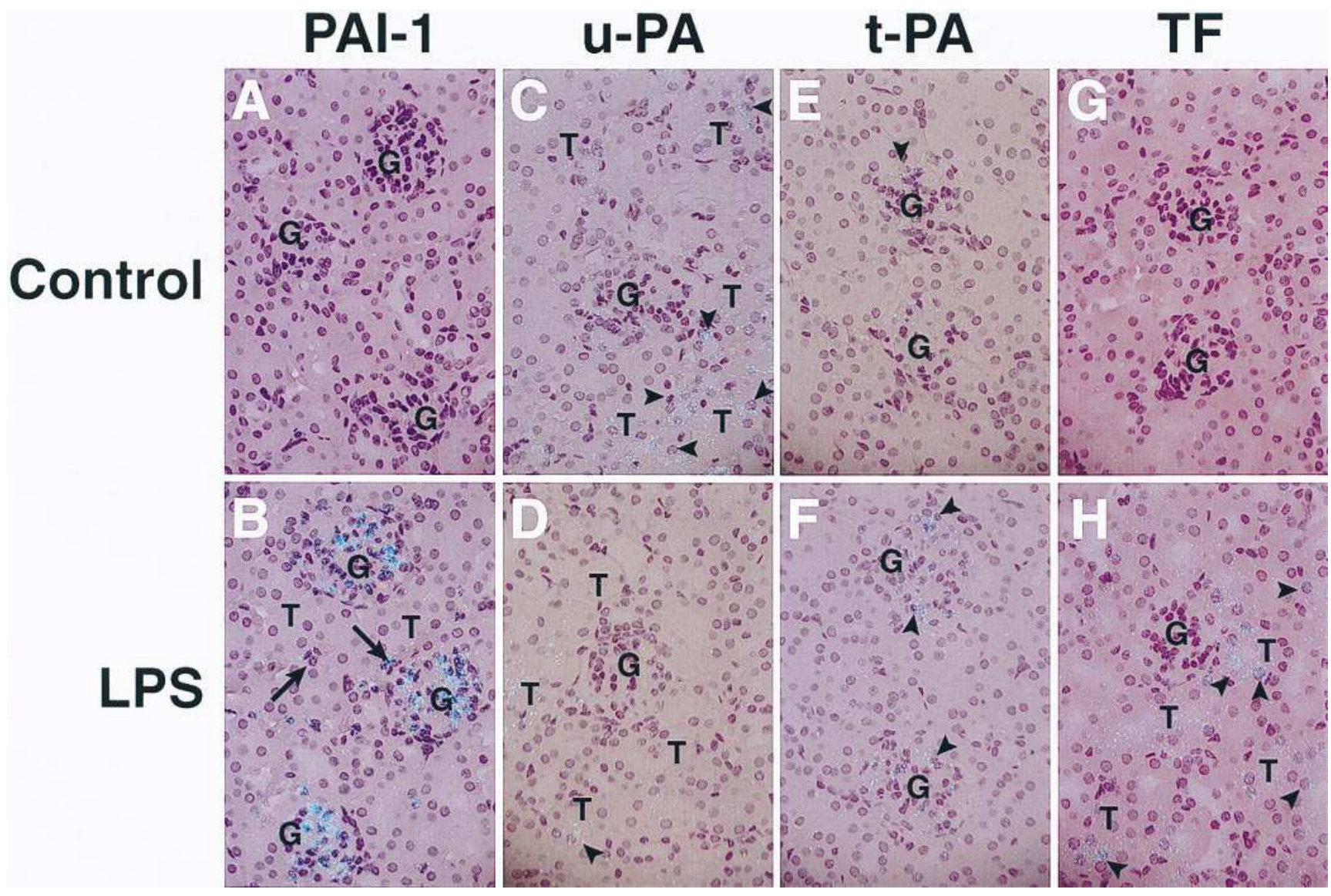

Figure 4. Localization of t-PA, u-PA, PAI-1, and TF mRNAs in kidney sections after LPS treatment. Kidney sections from control and LPStreated mice were hybridized to ${ }^{35}$ S-labeled riboprobes and prepared for high resolution in situ hybridization as described in Methods. $A$ and $B$ show the hybridization signals (blue grains) for PAI- 1 mRNA in the renal cortex of control mice $(A, \times 400)$ and LPS-treated $(3 \mathrm{~h})$ mice $(B, \times 400$; arrows denote peritubular endothelial cells). Slides were exposed for $6 \mathrm{wk}$ at $4^{\circ} \mathrm{C}$ and then stained with hematoxylin and eosin. $C$ and $D$ show the u-PA mRNA signal in the outer medulla of control mice $(C, \times 400)$ and LPS-treated $(3 \mathrm{~h})$ mice $(D, \times 400)$. Arrowheads denote positive signals in tubular epithelial cells in both panels. Slides were exposed for $3 \mathrm{wk}$ at $4^{\circ} \mathrm{C}$. $E$ and $F$ show t-PA mRNA in the renal cortex of control mice $(E$, $\times 400)$ and LPS-treated $(3 \mathrm{~h})$ mice $(F, \times 400)$. Arrowheads denote positive signals in glomerular cells in both panels. Slides were exposed for 6 wk at $4^{\circ} \mathrm{C}$. $G$ and $H$ show the TF mRNA signal in the renal cortex of control mice $(G, \times 400)$ and LPS-treated $(8 \mathrm{~h})$ mice $(H, \times 400)$. Arrowheads denote positive signals in tubular epithelial cells. Slides were exposed for $8 \mathrm{wk}$ at $4^{\circ} \mathrm{C}$. No specific hybridization signal could be detected in parallel sections using ${ }^{35}$ S-labeled sense probes for nonspecific hybridization. $G$, glomerulus; $T$, tubule.

demonstrate that both the number of fibrin-positive tissues and the duration of fibrin deposition in them were increased by administration of EACA before endotoxin.

\section{Discussion}

The primary hypothesis of the experiments summarized in this report is that fibrin deposition/dissolution in specific tissues during pathologic processes reflects temporal changes in the local expression of key procoagulant and fibrinolytic genes. To begin to address this hypothesis, we have determined the normal tissue distribution of TF, PAI-1, t-PA, and u-PA mRNAs in the mouse, and then treated mice with LPS to induce fibrin deposition. We then attempted to relate the presence of fibrin in tissues to changes in the expression of these genes. We have focused on TF, PAI-1, t-PA, and u-PA since each of these genes has been implicated in fibrin formation or removal and each is regulated during inflammatory/thrombotic events. The presence of fibrin was determined immunohistochemically. Moreover, sensitive-quantitative PCR assays were developed to determine the concentrations of these mRNAs in tissues since these genes were expected to be expressed in many tissues at levels below the detection level of Northern blot analysis. The sensitivity of PCR has been reported to be at least 1,000-fold higher than that of Northern blotting $(39,45,46)$. The detection limit of our system was 400-500 molecules $(\sim 0.001 \mathrm{pg})$ of endogenous target $\mathrm{mRNA} / \mu \mathrm{g}$ of total tissue RNA (data not shown). Because the cRNA standard used in these studies was designed to contain specific sequences for each gene, the concentrations of several mRNAs could be directly compared using the same standard (39).

In general, the tissue distribution and concentration of these mRNAs as determined by quantitative PCR (Fig. $1 B$ ) was similar to that determined previously using ribonuclease protection assays (26) or Northern blotting approaches $(13,47$, 48). For example, PAI-1 and t-PA mRNAs were detected in all tissues examined, although their concentrations varied over a wide range, and the expression of $\mathrm{u}-\mathrm{PA}$ was more restricted than that of the other genes, with the highest concentration by far being in the kidney. However, there were also some differ- 


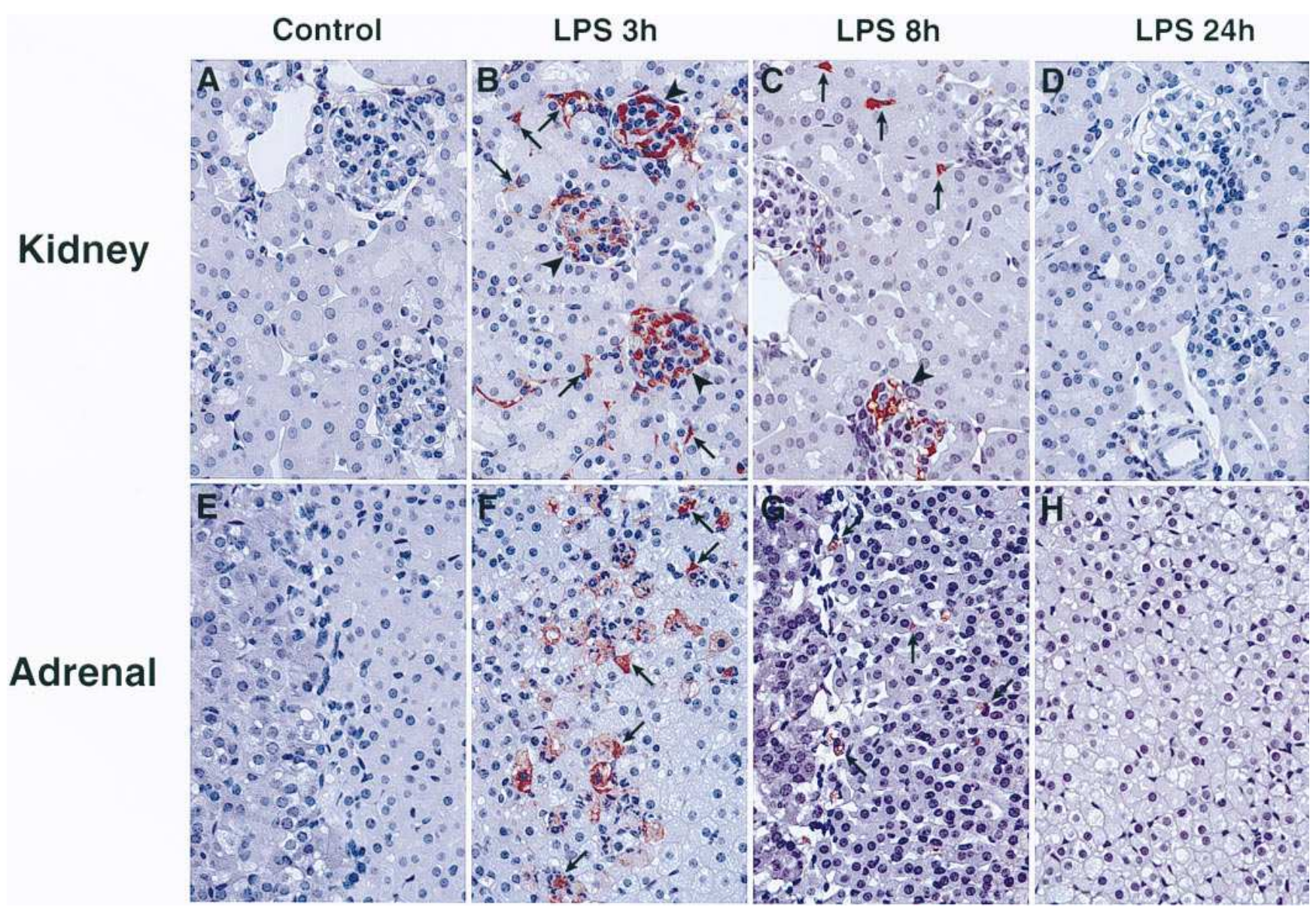

Figure 5. Fibrin deposition in the kidneys and adrenals from LPS-treated mice. Mice were injected intraperitoneally with either $50 \mu \mathrm{g}$ LPS or with saline alone as a control. At 3, 8, and $24 \mathrm{~h}$ after LPS administration, the mice were killed and their tissues were removed and analyzed by immunohistochemistry for fibrin as described in Methods. $(A-D)$ Sections of kidney from untreated control mice $(A)$ and mice treated with LPS for $3(B), 8(C)$, and $24 \mathrm{~h}(D)$. Arrowheads indicate glomerular fibrin depositions and arrows indicate peritubular fibrin depositions. $(E-H)$ Sections of adrenal from control mice $(E)$ and mice treated with LPS for $3(F), 8(G)$, and $24 \mathrm{~h}(H)$. Arrows indicate microvascular fibrin depositions. $\times 400$.

ences. For example, although we could not detect TF mRNA in the spleen, gut, thymus, muscle, and liver by Northern blotting (13), it was readily demonstrated in these tissues by using quantitative PCR. Interestingly, we observed relatively high levels of all four mRNAs in adipose tissue, suggesting that the fat in tissues may influence tissue and possibly systemic fibrinolysis.

Once the distribution of t-PA, u-PA, PAI-1, and TF mRNAs was established in normal murine tissues, we began to investigate how the expression of these mRNAs was altered in selective tissues in response to LPS (Fig. 2). PAI-1 mRNA was rapidly induced in most tissues, with the most pronounced increase in the liver, kidney, adrenal, and lung. The steady state levels of TF mRNA were also increased by LPS in most tissues examined, although they were decreased in the heart and liver. The increases in TF and PAI-1 expression should simultaneously activate the coagulation cascade and inhibit the fibrinolytic system, and thus together would be expected to contribute to the hypercoagulable state induced by endotoxin. Although LPS also slightly stimulated t-PA mRNA expression in most tissues examined, this increase may not be associated with increased t-PA activity because of the concomitant and significantly higher upregulation of PAI-1 gene expression in the same tissues (Fig. 2) $(25,42)$. Unexpectedly, and in contrast to the effects of LPS on t-PA gene expression, LPS caused significant decreases in u-PA mRNA levels in several tissues. This LPS-induced decrease in u-PA mRNA was most pronounced in the kidney and adrenal and occurred with kinetics that were similar to those observed for the deposition of fibrin in these tissues (see below).

Endotoxemia in humans is frequently associated with widespread DIC and multiple organ failure (49). However, fibrin deposition after LPS administration to the mouse was restricted to the renal and adrenal vasculature (Fig. 5), and it was transient. This observation is consistent with the idea that the local expression levels of procoagulant and fibrinolytic genes in the tissues may be more important for fibrin deposition than the circulating levels of these proteins. In situ hybridization demonstrated increased PAI-1 mRNA in renal glomerular and peritubular endothelial cells in endotoxemic mice (41) (Fig. 4), and previous immunohistochemical experiments showed increased PAI-1 antigen in the same cells (41). LPS significantly elevated PAI-1 mRNA in vascular endothelial cells in murine adrenals as well (data not shown). The dramatic induction of PAI-1 gene expression in cells on the luminal surface of the vascular wall should contribute to LPS-induced microvascular 


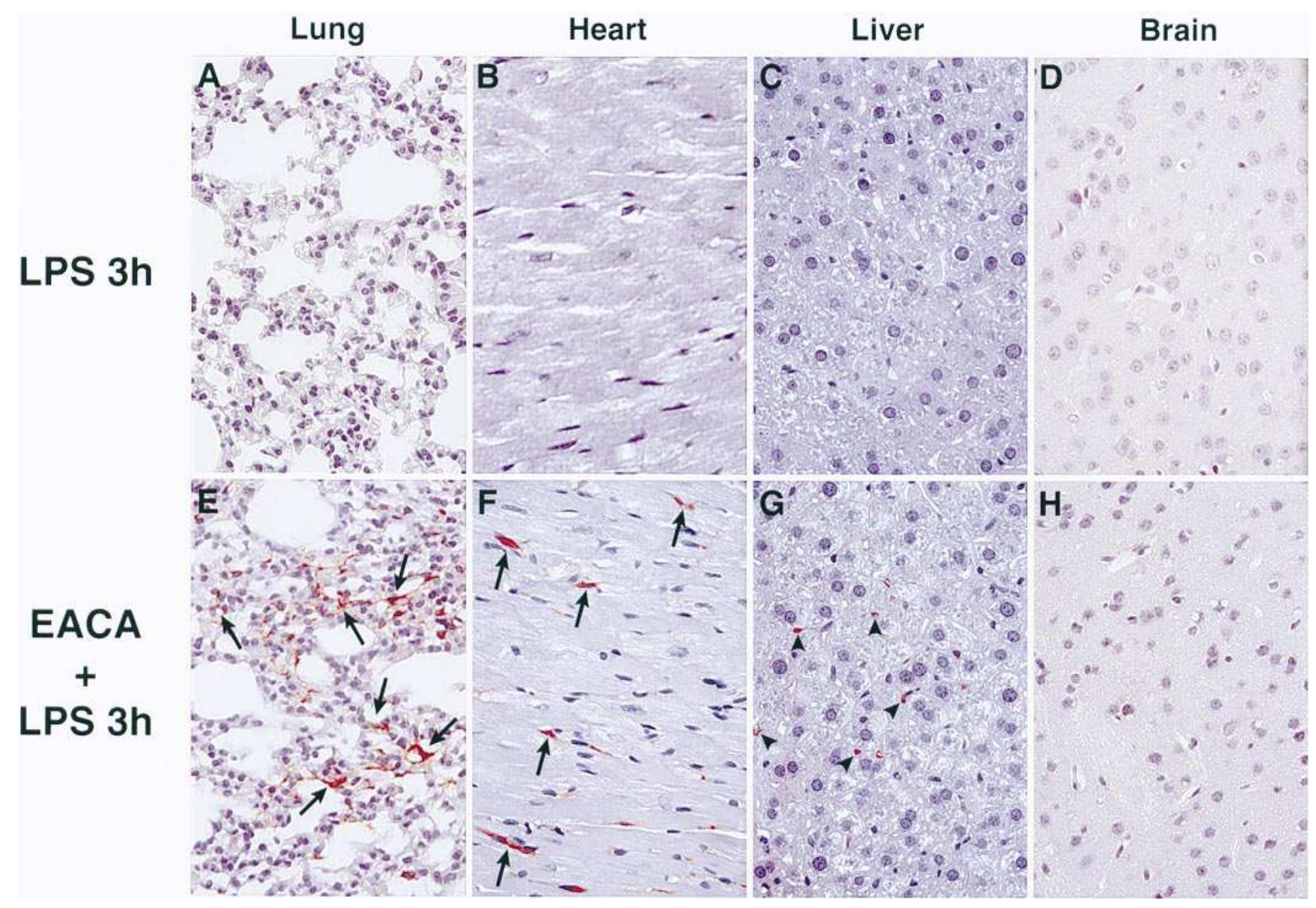

Figure 6. The effect of LPS and EACA on fibrin deposition in tissues. Mice were injected intraperitoneally either with $50 \mu \mathrm{g}$ LPS alone $(A-D)$ or with $20 \mathrm{mg}$ EACA $1 \mathrm{~h}$ before LPS injection $(E-H) .3 \mathrm{~h}$ after LPS administration, the mice were killed and their tissues were removed and analyzed for fibrin as described in Methods. ( $A$ and $E$ ) Sections of lung; arrows indicate fibrin deposits (red stain) in capillaries surrounding alveoli. $(B$ and $F$ ) Sections of heart; arrows indicate microvascular fibrin deposits in the myocardium. ( $C$ and $G)$ Sections of liver; arrowheads indicate sinusoidal fibrin deposits. $(D$ and $H$ ) Sections of brain. No fibrin was detected at this time. $\times 400$.

fibrin deposition in both tissues. The large increase in PAI-1 expression throughout the kidney and adrenal seems to be essential for fibrin deposition in both tissues since fibrin was not detected in kidneys and adrenals of PAI-1-deficient mice treated with LPS (our unpublished observation) (these animals were kindly provided by Dr. P. Carmeliet and Dr. D. Collen, University of Leuven) (50). In situ hybridization experiments also revealed a dramatic decrease in u-PA mRNA in tubular epithelial cells in the renal medulla after LPS injection (Figs. 3 and 4), consistent with previous work showing an LPSmediated reduction of u-PA mRNA and enzymatic activity (51). The LPS-induced decrease in u-PA expression may also contribute to fibrin deposition in peritubular microvessels. These experiments also revealed that TF mRNA was induced primarily in the renal cortex (Fig. 3) and that the responsible cells for the induction of TF mRNA were tubular epithelial cells (Fig. 4). The increase in TF expression in the tubular cells may contribute to peritubular fibrin deposition in the kidney from endotoxemic mice. Our results are consistent with clinical observations that the major problems in gram-negative septic patients are renal and adrenal failure due to microthrombi in small vessels in these tissues. This pathology is also typically observed in Waterhouse-Friderichsen syndrome caused by meningococcal bacteremia (52). Although the lung and liver are also commonly affected by microthrombi in DIC patients (53) and in DIC induced in animals by thrombin (54), no fibrin was detected in these tissues in our studies (Fig. 6, $A$ and $C$ ). This difference may reflect the fact that in our model the mice were exposed to a single injection of endotoxin, while in the septic patients, endotoxin is continuously produced.

Of the four variables measured in this study, the major difference in tissues developing fibrin (i.e., the kidney and adrenal) compared with those that do not (i.e., the lung) was the decrease in u-PA mRNA. This observation suggests an active role for u-PA in fibrin surveillance, a hypothesis which is supported by the observation that $\mathrm{u}-\mathrm{PA}$-deficient mice occasionally developed mild spontaneous and significant inflammationinduced fibrin deposition in tissues, but t-PA-deficient mice did not (55). This observation is especially noteworthy given the classical view of t-PA as the primary fibrinolytic enzyme (18). Moreover, these results indicate that the increase in the expression of PAI-1 and/or TF does not appear to be sufficient for fibrin deposition in tissues, although increases in both PAI-1 and TF expression appear to be necessary for fibrin deposition. These conclusions are based on the observation that no fibrin was detected in the liver of LPS-treated mice, in spite of 


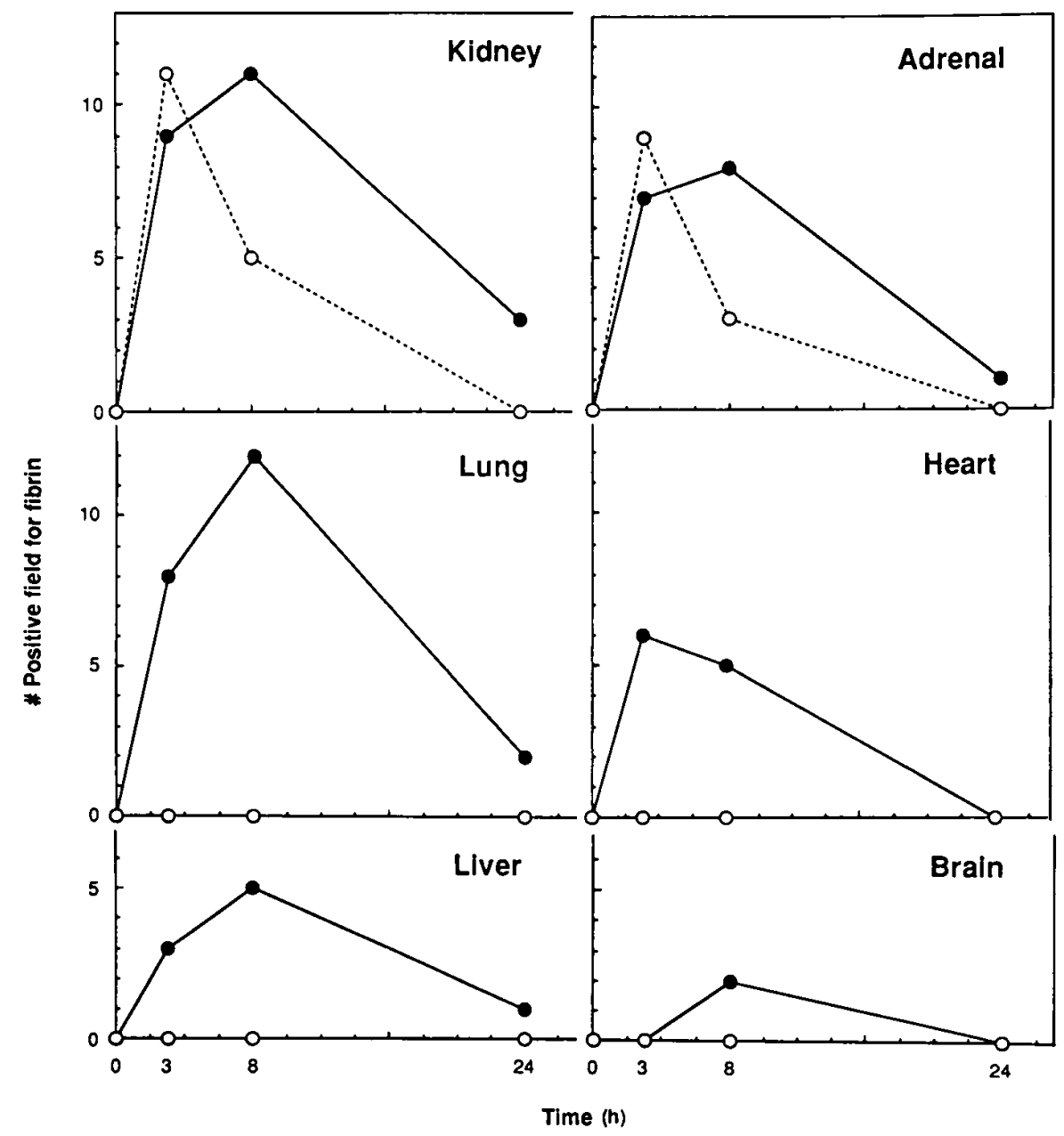

Figure 7. Quantitative evaluation of fibrin deposition in tissues from mice injected with EACA and LPS. Mice were injected intraperitoneally with either $50 \mu \mathrm{g}$ LPS alone (open circles) or with $20 \mathrm{mg}$ EACA $1 \mathrm{~h}$ before LPS administration (filled circles). At 3, 8, and $24 \mathrm{~h}$ after LPS injection, mice were killed and the tissues were removed. Mice injected with saline alone or EACA alone also were killed at $3 \mathrm{~h}$ after injection as controls (0 time point) in each group. Serial sections from three adult CB6 mice in each group were analyzed by immunohistochemistry for fibrin as described in Methods. Quantitation was achieved by counting the number of fibrin-positive fields in a total of 30 microscopic fields in each tissue section $(\times 400)$. A positive field is defined as a field that contains at least three positive spots for fibrin deposition. Average number of positive fields for fibrin was plotted at each time point. the fact that PAI-1 mRNA increased over 200-fold (data not shown; 26). However, in this instance, TF mRNA also decreased by $80 \%$ (data not shown). Similarly, no fibrin was detected in the heart, even though PAI-1 mRNA was increased and u-PA mRNA decreased (Fig. 2). Again, LPS caused a significant decrease in TF mRNA in this tissue.

The observations that t-PA was induced in most tissues by LPS, and that the only tissues that developed detectable fibrin after LPS injection were those with decreased u-PA, suggest that the absence of fibrin in some tissues after endotoxin administration may result from an active endogenous fibrinolytic system in those tissues. To test this possibility, mice were pretreated with EACA to inhibit fibrinolysis and then challenged with endotoxin. Although treatment of mice with EACA alone did not induce fibrin, treatment of mice with both EACA and LPS not only extended the number of fibrin-positive tissues considerably but also increased the duration of fibrin deposition (Figs. 6 and 7). These results are consistent with clinical reports of extensive thrombosis in DIC after EACA therapy (56) and of increased tissue injury due to thrombosis after EACA administration in experimental DIC (28). Thus, these results support the above hypothesis that the absence of LPS-induced fibrin deposition in some tissues is due to the removal of fibrin by ongoing fibrinolysis. Moreover, they suggest that defective endogenous fibrinolysis can potentiate local fibrin deposition in the tissues in septicemia.

In conclusion, these mRNA studies suggest that fibrin depo- sition in tissue-specific vasculature requires activation of the coagulation cascade through induction of TF gene expression, and suppression of the fibrinolytic system through increased PAI-1 and decreased u-PA gene expression in the tissue itself. However, it should be noted that we have assumed throughout that all of the mRNAs are equally translated in the various tissues, and there are no direct data to support this assumption. In fact, t-PA is translationally controlled in the primary mouse oocyte (57), raising the possibility that differential translational control in tissues may dissociate the usual correspondence between mRNA and protein. Because of this, we have initiated similar studies to monitor changes in antigen expression in tissues from LPS-treated mice. It is also likely that other molecules will influence the balance between coagulation and fibrinolysis. In this regard, TF pathway inhibitor should be evaluated as well since it controls TF activity (58) and reduces mortality from septic shock (59). In any case, our data suggest that delineation of changes in the expression of procoagulant and fibrinolytic genes in a variety of pathological conditions in vivo will provide further insights into mechanisms that contribute to vascular diseases, including thrombosis.

\section{Acknowledgments}

The authors thank T. Thinnes for expert technical assistance, and J. Lapan and M. McRae for excellent secretarial assistance. 
This work was supported by National Institutes of Health grant HL-47819 (D.J. Loskutoff).

\section{References}

1. Cybulsky, M.I., M.K.W. Chan, and H.Z. Movat. 1988. Biology of disease: acute inflammation and microthrombosis induced by endotoxin, interleukin-1, and tumor necrosis factor and their implication in gram-negative infection. Lab. Invest. 58:365-378.

2. Kincaid-Smith, P., and J.A. Whitworth. 1989. Disseminated intravascular coagulation and the kidney. In Hemostasis and the Kidney. Butterworth \& Co., London. 191-198.

3. Coalson, J.J. 1986. Pathology of sepsis, septic shock, and multiple organ failure. In Perspective on Sepsis and Septic Shock. Society of Critical Care Medicine, Fullerton, CA. 27-59.

4. Morrison, D.C., and J.L. Ryan. 1987. Endotoxins and disease mechanisms. Annu. Rev. Med. 38:417-432.

5. Moore, K.L., S.P. Andreoli, N.L. Esmon, C.T. Esmon, and N.U. Bang. 1987. Endotoxin enhances tissue factor and suppresses thrombomodulin expression of human vascular endothelium in vitro. J. Clin. Invest. 79:124-130.

6. Edgington, T.S., N. Mackman, K. Brand, and W. Ruf. 1991. The structural biology of expression and function of tissue factor. Thromb. Haemostasis. 66:67-79.

7. Broze, G.J., Jr. 1982. Binding of human Factor VII and VIIa to monocytes. J. Clin. Invest. 70:526-535.

8. Gregory, S.A., J.H. Morrissey, and T.S. Edgington. 1989. Regulation of tissue factor gene expression in the monocyte procoagulant response to endotoxin. Mol. Cell. Biol. 9:2752-2755.

9. Crossman, D.C., D.P. Carr, E.G.D. Tuddenham, J.D. Pearson, and J.H. McVey. 1990. The regulation of tissue factor mRNA in human endothelial cells in response to endotoxin or phorbol ester. J. Biol. Chem. 265:9782-9787.

10. Osterud, B., and T. Flaegstad. 1983. Increased tissue thromboplastin activity in monocytes of patients with meningococcal infection related to an unfavorable prognosis. Thromb. Haemostasis. 49:5-7.

11. Warr, T.A., L.V.M. Rao, and S.I. Rapaport. 1990. Disseminated intravascular coagulation in rabbits induced by administration of endotoxin or tissue factor: effect of anti-tissue factor antibodies and measurement of plasma extrinsic pathway inhibitor activity. Blood. 75:1481-1489.

12. Drake, T.A., J. Cheng, A. Chang, and F.B. Taylor, Jr. 1993. Expression of tissue factor, thrombomodulin, and E-selectin in baboons with lethal Escherichia coli sepsis. Am. J. Pathol. 142:1458-1470.

13. Mackman, N., M.S. Sawdey, M.R. Keeton, and D.J. Loskutoff. 1993. Murine tissue factor gene expression in vivo: tissue and cell specificity and regulation by lipopolysaccharide. Am. J. Pathol. 143:76-84.

14. Vassalli, J.D., A. Sappino, and D. Belin. 1991. The plasminogen activator/plasmin system. J. Clin. Invest. 88:1067-1072.

15. Dano, K., P.A. Andreasen, J. Grondahl-Hansen, P. Kristensen, L.S. Nielsen, and L. Skriver. 1985. Plasminogen activators, tissue degradation, and cancer. Adv. Cancer Res. 44:139-266.

16. Kristensen, P., L.I. Larsson, L.S. Nielsen, J. Grondahl-Hansen, P.A. Andreasen, and K. Dano. 1984. Human endothelial cells contain one type of plasminogen activator. FEBS Lett. 168:33-37.

17. Hoylaerts, M., D.C. Rijken, H.R. Lijnen, and D. Collen. 1982. Kinetics of the activation of plasminogen by human tissue plasminogen activator: role of fibrin. J. Biol. Chem. 257:2912-2919.

18. Collen, D., and H.R. Lijnen. 1991. Basic and clinical aspects of fibrinolysis and thrombolysis. Blood. 78:3114-3124.

19. Vassalli, J.-D., J.-M. Dayer, A. Wohlwend, and D. Belin. 1984. Concomitant secretion of prourokinase and of a plasminogen activator-specific by cultured human monocytes-macrophages. J. Exp. Med. 159:1653-1668.

20. Vassalli, J.-D., D. Baccino, and D. Belin. 1985. A cellular binding site for the $M_{\mathrm{r}} 55,000$ form of the human plasminogen activator, urokinase. J. Cell Biol. 100:86-92.

21. Blasi, F., J. Vassalli, and K. Dano. 1987. Urokinase-type plasminogen activator. Proenzyme, receptor, and inhibitors. J. Cell Biol. 104:801-804.

22. Loskutoff, D.J., M. Sawdey, and J. Mimuro. 1988. Type 1 plasminogen activator inhibitor. In Progress in Hemostasis and Thrombosis. B. Coller, editor. W.B. Saunders Co., Philadelphia. 87-115.

23. Hamsten, A., B. Wiman, U. deFaire, and M. Blomback. 1985. Increased plasma levels of a rapid inhibitor of tissue plasminogen activator in young survivors of myocardial infarction. N. Engl. J. Med. 313:1557-1563.

24. Tabernero, M.D., A. Estélles, V. Vicente, I. Alberca, and J. Aznar. 1989. Incidence of increased plasminogen activator inhibitor in patients with deep venous thrombosis and/or pulmonary embolism. Thromb. Res. 56:565570 .

25. Quax, P.H.A., C.M. van den Hoogen, J.H. Verheijen, T. Padro, R. Zeheb, T.D. Gelehrter, T.J.C. van Berkel, J. Kuiper, and J.J. Emeis. 1990. Endotoxin induction of plasminogen activator and plasminogen activator inhibitor type $1 \mathrm{mRNA}$ in rat tissues in vivo. J. Biol. Chem. 265:15560-15563.

26. Sawdey, M.S., and D.J. Loskutoff. 1991. Regulation of murine type 1 plasminogen activator inhibitor gene expression in vivo. Tissue specificity and induction by lipopolysaccharide, tumor necrosis factor- $\alpha$, and transforming growth factor- $\beta$. J. Clin. Invest. 88:1346-1353.

27. Fearns, C., T. Thinnes, K. Roegner, and D.J. Loskutoff. 1993. Kinetics of induction of PAI-1 gene expression on liver endothelial cells and hepatocytes by lipopolysaccharide (LPS). Thromb. Haemostasis. 69:757a. (Abstr.)

28. Saldeen, T. 1970. The importance of intravascular coagulation and inhibition of the fibrinolytic system in experimental fat embolism. J. Trauma. 10: 287-298.

29. Chomczynski, P., and N. Sacchi. 1987. Single-step method of RNA isolation by acid guanidinium thiocyanate-phenol-chloroform extraction. Anal. Biochem. 162:156-159.

30. Rickles, R.J., A.L. Darrow, and S. Strickland. 1988. Molecular cloning of complementary DNA to mouse tissue plasminogen activator mRNA and its expression during F9 teratocarcinoma cell differentiation. J. Biol. Chem. 263: 1563-1569.

31. Belin, D., J.-D. Vassalli, C. Combepine, F. Godeau, Y. Nagamine, E. Reich, H.P. Kocher, and R.M. Duvosin. 1985. Cloning, nucleotide sequencing and expression of cDNAs encoding mouse urokinase-type plasminogen activator. Eur. J. Biochem. 148:225-232.

32. Prendergast, G.C., L.E. Diamond, D. Dahl, and M.D. Cole. 1990. The c-myc-regulated gene mr1 encodes plasminogen activator inhibitor 1. Mol. Cell. Biol. 10:1265-1269.

33. Mackman, N., S. Imes, W.H. Maske, B. Taylor, A.J. Lusis, and T.A. Drake. 1992. Structure of the murine tissue factor gene. Chromosome location and conversation of regulatory elements in the promoter. Arterioscler. Thromb. 12:474-483.

34. Derynck, R., J.A. Jarrett, E.Y. Chen, and D.V. Goeddel. 1986. The murine transforming growth factor- $\beta$ precursor. J. Biol. Chem. 261:4377-4379.

35. Seiffert, D., M. Keeton, Y. Eguchi, M. Sawdey, and D.J. Loskutoff. 1991. Detection of vitronectin mRNA in tissues and cells of the mouse. Proc. Natl. Acad. Sci. USA. 88:9402-9406.

36. Nichols, W.C., K.A. Cooney, K.L. Mohlke, J.D. Ballew, A. Yang, M.E. Bruck, M. Reddington, E.K. Novak, R.T. Swank, and D. Ginsberg. 1994. von Willebrand disease in the RIIIS/J mouse is caused by a defect outside of the von Willebrand factor gene. Blood. 83:3225-3231.

37. Tokunaga, K., H. Taniguchi, K. Yoda, M. Shimizu, and S. Sakiyama 1986. Nucleotide sequence of a full-length cDNA for mouse cytoskeletal $\beta$-actin mRNA. Nucleic Acids Res. 14:2829.

38. Baldwin, G.S., and Q.-X. Zhang. 1992. Measurement of gastrin and transforming growth factor $\alpha$ messenger RNA levels in colonic carcinoma cell lines by quantitative polymerase chain reaction. Cancer Res. 52:2261-2267.

39. Wang, A.M., M.V. Doyle, and D.F. Mark. 1989. Quantitation of mRNA by the polymerase chain reaction. Proc. Natl. Acad. Sci. USA. 86:9717-9721.

40. Samad, F., K. Yamamoto, and D.J. Loskutoff. 1996. Distribution and regulation of plasminogen activator inhibitor-1 in murine adipose tissue in vivo. Induction by tumor necrosis factor- $\alpha$ and lipopolysaccharide. J. Clin. Invest. 97: $37-46$.

41. Keeton, M., Y. Eguchi, M. Sawdey, C. Ahn, and D.J. Loskutoff. 1993 Cellular localization of type 1 plasminogen activator inhibitor mRNA and protein in murine renal tissue. Am. J. Pathol. 142:59-70.

42. Suffredini, A.F., P.C. Harpel, and J.E. Parrillo. 1989. Promotion and subsequent inhibition of plasminogen activation after administration of intravenous endotoxin to normal subjects. N. Engl. J. Med. 320:1165-1172.

43. van Deventer, S.J.H., H.R. Buller, J.W. ten Cate, L.A. Aarden, C.E. Hack, and A. Sturk. 1990. Experimental endotoxemia in humans: analysis of cytokine release and coagulation, fibrinolytic, and complement pathways. Blood. 76:2520-2526.

44. McNicol, G.P., A.P. Fletcher, N. Alkjaersig, and S. Sherry. 1962. The absorption, distribution and excretion of epsilon-aminocaproic acid following oral or intravenous administration to man. J. Lab. Clin. Med. 59:15-21.

45. Murray, L.J., R. Lee, and C. Martens. 1990. In vivo cytokine gene expression in T cell subsets of the autoimmune MRL/Mp-lpr/lpr mouse. Eur. J. Immunol. 20:163-170.

46. Platzer, C., G. Richter, K. Überla, W. Müller, H. Blöcker, T. Diamantstein, and T. Blankenstein. 1992. Analysis of cytokine mRNA levels in interleukin-4-transgenic mice by quantitative polymerase chain reaction. Eur. J. Immunol. 22:1179-1184.

47. Rickles, R.J., and S. Strickland. 1988. Tissue plasminogen activator mRNA in murine tissues. FEBS Lett. 229:100-106.

48. Almus-Jacobs, F., N. Varki, M.S. Sawdey, and D.J. Loskutoff. 1995. Endotoxin stimulates murine urokinase-type plasminogen activator receptor gene expression in vivo. Am. J. Pathol. 147:688-698.

49. Kreger, B., D. Craven, and W. McCabe. 1980. Gram-negative bacteremia. IV. Re-evaluation of clinical features and treatment in 612 patients. Am. J. Med. 68:344-355.

50. Carmeliet, P., J.M. Stassen, L. Schoonjans, B. Ream, J.J. Van den Oord, M. De Mol, R.C. Mulligan, and D. Collen. 1993. Plasminogen activator inhibitor-1 gene-deficient mice. II. Effects on hemostasis, thrombosis, and thrombolysis. J. Clin. Invest. 92:2756-2760.

51. Moll, S., J.A. Schifferli, J. Huarte, R. Lemoine, J.-D. Vassalli, and A.-P. Sappino. 1994. LPS induces major changes in the extracellular proteolytic bal- 
ance in the murine kidney. Kidney Int. 45:500-508.

52. McGehee, W.G., S.I. Rapaport, and P.F. Hjort. 1967. Intravascular coagulation in fluminant meningococcemia. Ann. Intern. Med. 67:250-260.

53. Shimamura, K., K. Oka, M. Natazawa, and M. Kojima. 1983. Distribution patterns of microthrombi in disseminated intravascular coagulation. Arch. Pathol. Lab. Med. 107:543-547.

54. Craane, H., J.J. Emeis, J. Lindeman, and W. Nieuwenhuizen. 1978. Immunoenzymehistochemical detection of fibrin microthrombi during disseminated intravascular coagulation in rats. Histochemistry. 57:97-105.

55. Carmeliet, P., L. Schoonjans, L. Kieckens, B. Ream, J. Degen, R. Bronson, R. De Vos, J.J. Van den Oord, D. Collen, and R.C. Mulligan. 1994. Physiological consequences of loss of plasminogen activator gene function in mice. Nature (Lond.). 368:419-424.
56. Charytan, C., and D. Purtilio. 1969. Glomerular capillary thrombosis and acute renal failure after epsilon-amino caproic acid therapy. N. Engl. J. Med. 280:1102-1104.

57. Vassalli, J.-D., J. Huarte, D. Belin, P. Gubler, A. Vassalli, M.L. O'Connell, L.A. Parton, R.J. Rickles, and S. Strickland. 1989. Regulated polyadenylation controls mRNA translation during meiotic maturation of mouse oocytes. Genes \& Dev. 3:2163-2171.

58. Rapaport, S.I. 1991. Regulation of the tissue factor pathway. Ann. NY Acad. Sci. 614:51-62.

59. Creasey, A.A., A.C.K. Chang, L. Feigen, T.-C. Wün, F.B. Taylor, Jr., and L.B. Hinshaw. 1993. Tissue factor pathway inhibitor reduces mortality from Escherichia coli septic shock. J. Clin. Invest. 91:2850-2860. 